\title{
SYNTHESIS AND CHARACTERIZATION OF COBALT (III) COMPLEX OF SALICYLALDEHYDE BENZOYL HYDRAZONE
}

\section{Sabita Shrestha}

Journal of Institute of Science and Technology

Volume 22, Issue 1, July 2017

ISSN: 2469-9062 (print), 2467-9240 (e)

\section{Editors:}

Prof. Dr. Kumar Sapkota

Prof. Dr. Armila Rajbhandari

Assoc. Prof. Dr. Gopi Chandra Kaphle

JIST, 22 (1): 132-136 (2017)

Published by:

Institute of Science and Technology

Tribhuvan University

Kirtipur, Kathmandu, Nepal 


\title{
SYNTHESIS AND CHARACTERIZATION OF COBALT (III) COMPLEX OF SALICYLALDEHYDE BENZOYL HYDRAZONE
}

\author{
Sabita Shrestha \\ Central Department of Chemistry, Tribhuvan University, Kirtipur, Nepal \\ Corresponding E-mail: shresthasabita@hotmail.com
}

\begin{abstract}
Cobalt Complex of type $\left[\mathrm{Co}(\mathrm{Hsbh})_{2}\left(\mathrm{NO}_{3}\right)\left(\mathrm{H}_{2} \mathrm{O}\right)\right] .3 \mathrm{H}_{2} \mathrm{O}$ was synthesized and characterized by different analytical procedures, molar conductance, infrared and electronic spectral studies. The complex was found to be 1:2 metal ligand ratio. Molar conductance measurement shows non electrolyte nature of complex. Dehydration studies indicate the presence of coordinated as well as lattice water molecules. Infrared spectral studies indicate that ligand undergo keto enol tautomerism and bond to the metal ion via enolic oxygen and $\mathrm{NH}_{2}$ group. The electronic spectrum shows octahedral geometry around central cobalt (III) atom.
\end{abstract}

Keywords: Schiff base, Co (III) ion, IR spectra, Electronic spectra, Tautomerism.

\section{INTRODUCTION}

Hydrazide Schiff base or hydrazones are those compounds which contain azomethine group $>\mathrm{C}=\mathrm{N}$ - and are usually formed by the condensation of acyl hydrazines and their derivatives with an active carbonyl group, viz., aldehyde and ketone (Zabicky, 1970). Because of the presence of several bonding sites and possibility of keto-enol tautomerism, these compounds can act as multidentate chelating ligands. Schiff bases offer a versatile and flexible series of ligands capable of binding many metal ions to give complexes with

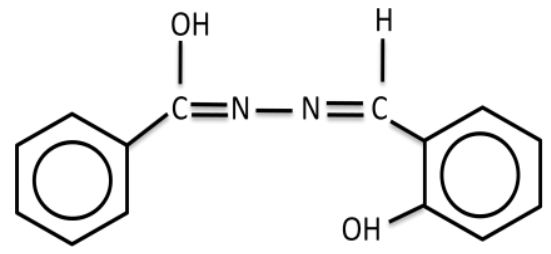

[1] suitable properties for many theoretical and practical applications (Bandin, 1994). Because of their biological activities and various bonding, when forming complexes with transition metals, the coordination chemistry of hydrazone has attracted the attention of many investigators (Demirelli, 2006; Yongxiang, 1989; Shrestha \& Maharjan, 2012; Shrestha, 2013).

The Schiff Base or Hydrazone can coordinate to transition metals either in the enolic form (1) or in ketonic (2) form as shown in figure 1.

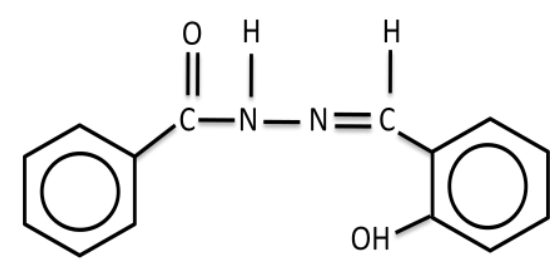

[2]

Fig 1. Enolic [1] and Ketonic [2] forms of salicylaldehyde benzoyl hydrazone.

This paper reports the synthesis of Cobalt(III) complex of Schiff base: salicylaldehyde benzoyl hydrazone and characterization by various physicochemical studies.

\section{MATERIALS AND METHODS}

\section{Starting Materials}

Transition metal salt $\mathrm{Co}\left(\mathrm{NO}_{3}\right)_{2} 6 \mathrm{H}_{2} \mathrm{O}$ was obtained from SD fine chemical Ltd (Mumbai, India). Ethyl benzoate was of $\mathrm{CDH}$ Laboratory Reagent, New
Delhi. The solvents ethanol and benzene were purchased from Qualigens Chemical Company and used without further purification.

\section{Synthesis of Ligand}

The ligand, salicylaldehyde benzoyl hydrazone was prepared in following two steps.

Synthesis of the Benzoic Hydrazide (bh)

The ligand, benzoic acid hydrazide, $\mathrm{C}_{6} \mathrm{H}_{5} \mathrm{CONHNH}_{2}$ (bh) was prepared (Scheme 1) by following literature procedure (Narang, 1996) by 
refluxing together ethanolic solutions of ethyl benzoate $(30 \mathrm{ml})$ with hydrazine hydrate $(10 \mathrm{ml})$ in 1:1 mole ratio for about six to eight hours followed by leaving the solution overnight. The products were filtered and thoroughly washed with distilled water. Thus obtained hydrazide was recrystallized from hot benzene.
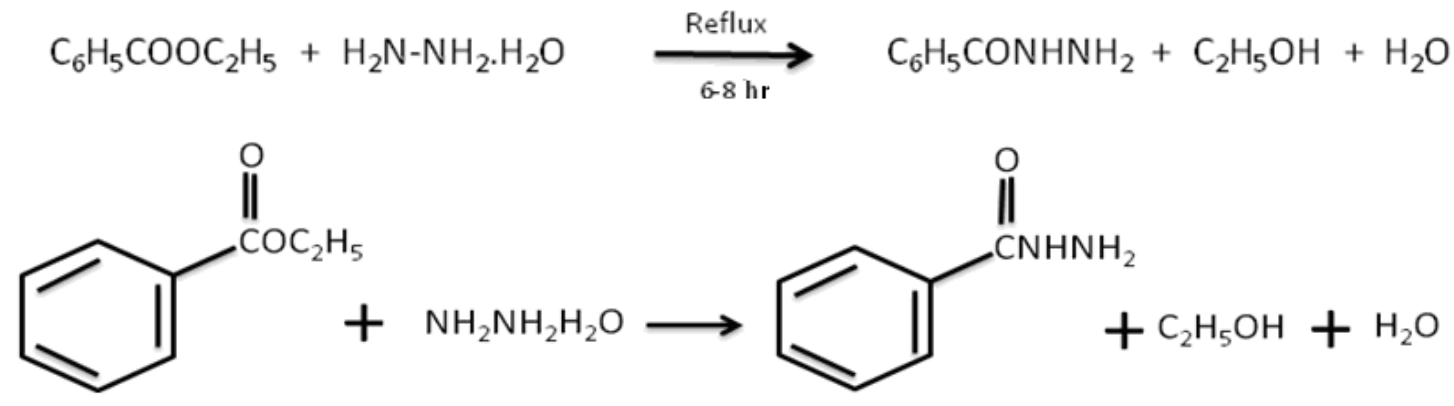

Scheme 1. Synthesis of Benzoic Acid hydrazide.

Synthesis of Salicylaldehyde Benzoyl Hydrazone $\left(\mathbf{H}_{2} \mathbf{s b h}\right)$

Hydrazide Schiff base or hydrazone is prepared by condensation of hydrazide with a compound containing active carbonyl group, i. e. aldehyde or ketone. Aldehydes, in general, yield $\mathrm{N}$-amido aldimines while ketones yield $\mathrm{N}$-amido ketimines (Zabicky, 1970). In this work, salicylaldehyde benzoyl hydrazone $\left(\mathrm{H}_{2} \mathrm{sbh}\right)$, a hydrazide Schiff base was prepared by condensation of benzoic acid hydrazide (5.44 $\mathrm{g}$ dissolved in ethanol) with salicylaldehyde $(4.88 \mathrm{~g}$ or $4.1 \mathrm{ml}$; wt per $\mathrm{ml}=1.19$ g) (Scheme 2) in 1:1 mole ratio. After mixing these two solutions, it was heated for few minutes and left overnight. The light yellow crystalline solid formed was then filtered and washed 2-3 times with ethanol and left to dry. The yield was found to be $78 \%$ and the m. p. was found to be $177^{\circ} \mathrm{C}$.

$$
\begin{aligned}
& \mathrm{RCONHNH}_{2}+\mathrm{R}^{\prime} \mathrm{CHO} \longrightarrow \mathrm{RCONHN}=\mathrm{CHR}^{\prime}+\mathrm{H}_{2} \mathrm{O} \\
& \text { (Acyl hydrazine) } \text { (Aldehyde) } \\
& \text { (N-amido aldimines) }
\end{aligned}
$$

Where, $\mathrm{R}=-\mathrm{C}_{6} \mathrm{H}_{5}$ and $\mathrm{R}^{\prime}=-\mathrm{C}_{6} \mathrm{H}_{4}(\mathrm{OH})$<smiles></smiles>

Scheme 2. Synthesis of Salicylaldehyde Benzoyl Hydrazone.

\section{Characterization of Ligand}

The structure of the prepared ligand (Figure 2.) was established on the basis of melting point, hydrazine estimation and infrared data.

\section{Synthesis of Complex}

Ethanolic solutions of ligand, $\mathrm{H}_{2} \mathrm{sbh}(5 \mathrm{mmol} / 1.2 \mathrm{~g}$ in $50 \mathrm{ml})$ and $\mathrm{Co}\left(\mathrm{NO}_{3}\right)_{2} 6 \mathrm{H}_{2} \mathrm{O}(5 \mathrm{mmol} / 1.4 \mathrm{~g}$ in 10 $\mathrm{ml}$ ) were mixed and heated for few minutes on the water bath which resulted in the formation of brick red precipitate. It was then left overnight. The precipitate formed was then filtered, washed with ethanol and dried over fused $\mathrm{CaCl}_{2}$.<smiles>O=C(N=Cc1ccccc1)c1ccccc1O</smiles>

Fig. 2. Salicylaldehyde benzoyl hydrazone. 


\section{Analysis of Complex \\ Estimation of Ligand}

The ligand content in the synthesized complex was estimated by calibration curve method (Narang, 2000). In this method, a weighed quantity of the complex was dissolved in $10 \mathrm{ml}$ of $6 \mathrm{~N} \mathrm{HCl}$ and titrated against a standard solution $(\sim 0.1 \mathrm{~N})$ of $\mathrm{KBrO}_{3}$ using methyl orange as indicator. The ligand content was adjudged from a calibration curve which was constructed by plotting the data of at least five sets of titrations where, in each case, a varying amount of the ligand was dissolved in $10 \mathrm{ml}$ of $6 \mathrm{~N} \mathrm{HCl}$ and the solution was titrated against a standard solution of $\mathrm{KBrO}_{3}$.

\section{Estimation of Metal}

The amount of cobalt in complex was estimated by complexometric titration (Vogel, 1978). For this about $0.1 \mathrm{~g}$ of the complex was accurately weighed and digested with conc. $\mathrm{H}_{2} \mathrm{SO}_{4}$ followed by conc. $\mathrm{HNO}_{3}$ and finally with aqua regia. The resulting residue was extracted with $1: 1 \mathrm{HCl}$ and water was added to it. Hexamine buffer was added to the resulting solution till the $\mathrm{pH}$ was 6 . The $\mathrm{pH}$ was maintained using $\mathrm{pH}$ meter. It was then titrated against standard EDTA solution using xylenol orange indicator till the color changed from red to light yellow. The amount of cobalt was calculated by using relation.

$$
1 \mathrm{ml} \text { of } 1 \mathrm{M} \text { EDTA } \equiv 0.0589 \mathrm{gm} \text { of Cobalt }
$$

\section{Estimation of Water Molecules (Dehydration Studies)}

The dehydration studies of Cobalt complex showed weight loss occurring at temperature $110^{\circ} \mathrm{C}$ and $150^{\circ} \mathrm{C}$ which is equivalent to three lattice and one coordinated water molecules respectively.

\section{RESULTS AND DISCUSSION}

\section{General Behavior}

The ligand, salicylaldehyde benzoyl hydrazone in this study form 1:2 (M : L) complex. The reaction between the ligand and metal salt is represented by following equation:

$$
\mathrm{Co}\left(\mathrm{NO}_{3}\right)_{2} 6 \mathrm{H}_{2} \mathrm{O}+2\left(\mathrm{H}_{2} \mathrm{sbh}\right) \rightarrow\left[\mathrm{Co}(\mathrm{Hsbh})_{2}\left(\mathrm{NO}_{3}\right)\left(\mathrm{H}_{2} \mathrm{O}\right)\right] \cdot 3 \mathrm{H}_{2} \mathrm{O}+2 \mathrm{HNO}_{3}+2 \mathrm{H}_{2} \mathrm{O}
$$

The complex is intensely colored and stable powder, which start melt at $270^{\circ} \mathrm{C}$ and completed at $280^{\circ} \mathrm{C}$. The yield of the complex was found to be $50 \%$ (Table 1). The molar conductance value
(23 $\left.\Omega-1 \mathrm{~cm}^{2} \mathrm{~mole}^{-1}\right)$ showed non- electrolyte nature (Geary, 1971). The complex was insoluble in water, ethanol and benzene and soluble in dimethyl sulphoxide and dimethyl formamide.

Table 1. Analytical Data of Cobalt Complex of Salicyaldehyde Benzoyl Hydrazone.

\begin{tabular}{|l|l|l|l|l|l|l|}
\hline $\begin{array}{l}\text { Complex, Colour } \\
\text { Yield }(\%)\end{array}$ & $\begin{array}{l}\text { Empirical Formula } \\
(\text { Formula Wt. })\end{array}$ & $\begin{array}{l}\text { M. P. } \\
\left({ }^{\circ} \mathrm{C}\right)\end{array}$ & $\begin{array}{l}\text { Metal } \\
(\%)\end{array}$ & $\begin{array}{l}\text { Ligand } \\
(\%)\end{array}$ & $\begin{array}{l}\text { Lattice } \\
\text { water }(\%)\end{array}$ & $\begin{array}{l}\text { Coordinate } \\
\text { water }(\%)\end{array}$ \\
\hline $\begin{array}{l}{\left[\mathrm{Co}(\mathrm{Hsbh})_{2}\left(\mathrm{NO}_{3}\right)\left(\mathrm{H}_{2} \mathrm{O}\right)\right] .3 \mathrm{H}_{2} \mathrm{O} \mathrm{O}} \\
\text { Brick red, }(50 \%)\end{array}$ & $\begin{array}{l}\mathrm{CoC}_{28} \mathrm{H}_{24} \mathrm{O}_{8} \mathrm{~N}_{5} \\
(617)\end{array}$ & $270-280$ & $\begin{array}{l}9.01 \\
(9.56)\end{array}$ & $\begin{array}{l}80.5 \\
(77.47)\end{array}$ & $\begin{array}{l}8.64 \\
(8.75)\end{array}$ & $\begin{array}{l}2.47 \\
(2.90)\end{array}$ \\
\hline
\end{tabular}

\section{Infrared Spectra Studies}

The assignments of IR spectral bands are most useful in establishing the structural identity of the ligand and its complexes. The band positions of ligand and complex are listed in table 2 .

\begin{tabular}{|c|c|c|c|c|c|c|}
\hline $\begin{array}{l}\text { Ligand } \\
\text { Complex }\end{array}$ & $\begin{array}{l}v(\mathrm{OH})+ \\
v(\mathrm{NH})\end{array}$ & $v(\mathrm{C}=\mathrm{N})$ & $\begin{array}{l}\text { Amide } \\
\text { I }\end{array}$ & $\begin{array}{l}\text { Amide } \\
\text { II }\end{array}$ & $\begin{array}{l}\text { Amide } \\
\text { III }\end{array}$ & $v(\mathrm{~N}-\mathrm{N})$ \\
\hline $\mathrm{H}_{2} \mathrm{sbh}$ & 3280 & $1630_{\mathrm{m}}$ & $1675_{\mathrm{s}}$ & $1535_{\mathrm{s}}$ & $1275_{\mathrm{s}}$ & $995_{w}$ \\
\hline \multirow[t]{2}{*}{$\mathrm{Co}(\mathrm{Hsbh})_{2}$} & $v(\mathrm{OH})$ & \multicolumn{2}{|c|}{$>\mathrm{C}=\mathrm{N}-\mathrm{N}=\mathrm{C}<$} & $\underline{v \mathrm{NCO}^{-}}$ & & \\
\hline & $3440_{b}$ & \multicolumn{2}{|c|}{$1595_{\mathrm{s}}$} & $1525_{\mathrm{w}}$ & & $1030_{\mathrm{w}}$ \\
\hline
\end{tabular}

Table 2. Important IR Spectral Data $\left(\mathrm{cm}^{-1}\right)$ of $\left[\mathrm{Co}(\mathrm{Hsbh})_{2}\left(\mathrm{NO}_{3}\right)\left(\mathrm{H}_{2} \mathrm{O}\right)\right] .3 \mathrm{H}_{2} \mathrm{O}$

$\mathrm{s}=$ sharp, ${ }_{\mathrm{b}}=$ Broad $_{\mathrm{w}}=$ weak, $\mathrm{m}=$ medium 
In the spectrum of ligand, $\mathrm{H}_{2} \mathrm{sbh}$ the absorption bands at 3280, 1675, 1630, 1535, 1275 and 995 $\mathrm{cm}^{-1}$ have been attributed to $v(\mathrm{~N}-\mathrm{H}) / v(\mathrm{OH})$, amide $\mathrm{I}, v(\mathrm{C}=\mathrm{N})$, amide $\mathrm{II}$, amide $\mathrm{III}$ and $v(\mathrm{~N}-\mathrm{N})$ (Silverstein, 1981).

The IR spectra of complex $\left[\mathrm{Co}(\mathrm{Hsbh})_{2}\left(\mathrm{NO}_{3}\right)\left(\mathrm{H}_{2} \mathrm{O}\right)\right] \cdot 3 \mathrm{H}_{2} \mathrm{O}$ show the disappearance of all amide bands and $v(\mathrm{~N}-\mathrm{H})$ stretching bands indicating the destruction of $>\mathrm{C}=\mathrm{O}$ group and loss of $\mathrm{NH}$ proton via enolization and the ligand is coordinating in the enolic form (Mohan, 1987).

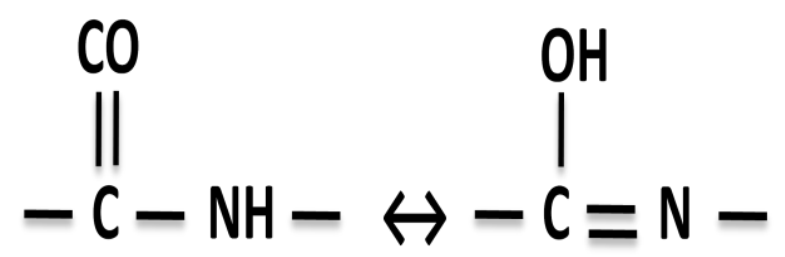

keto form

enol form

So, through enolisation, the IR spectra of the Cocomplex showed some new bands. A sharp band at $1595 \mathrm{~cm}^{-1}$ diagnostic of $>\mathrm{C}=\mathrm{N}-\mathrm{N}=\mathrm{C}<$ group (Sayeed, 1971) indicating transformation of the carbonyl group to its enolic form through ketoenol tautomerism and subsequent coordination of the enolic oxygen to metal after deprotonation. Again the appearance of a new band at $1525 \mathrm{~cm}^{-1}$ was characteristic of $v\left(\mathrm{NCO}^{-}\right)$vibration, which further supported the enolic oxygen coordination (Narang, 2000).

A weak band around $875 \mathrm{~cm}^{-1}$ due to the rocking mode of vibration, $\rho\left(\mathrm{H}_{2} \mathrm{O}\right)$, suggests (Nakamoto, 1997) the presence of coordinated water molecule in the complex, which was also shown by dehydration study.

The presence of additional bands at 1450 and 1295 $\mathrm{cm}^{-1}$ in the complex implies unidentate coordination of the nitrate group (Nakamoto, 1997). The broad band centered at $3440 \mathrm{~cm}^{-1}$ may be due to water molecule and - $\mathrm{OH}$ of salicylaldehyde part. The $v(\mathrm{~N}-\mathrm{N})$ vibration in the complex shifted to higher frequency $\left(\sim 35 \mathrm{~cm}^{-1}\right)$, shows coordination through one of the nitrogen atoms of the hydrazide moiety. This shifting of $v(\mathrm{~N}-\mathrm{N})$ vibration to higher frequency in Co-complex was attributed to the electron attracting inductive effect when forming the conjugate system (Narang, 2000).

\section{Electronic Spectra Studies}

Transition metal complexes often have absorption bands in the visible region coming from the combination of $\mathrm{d}-\mathrm{d}$ and charge transfer transitions. The Electronic spectra provide information regarding bonding and stereochemistry of the complexes. Co (III) is a $\mathrm{d}^{6}$ system and complexes can be high spin or low spin depending upon the type of the ligand. For $\mathrm{d}^{6}$ high spin (four unpaired electron) case, the ground state term is ${ }^{5} \mathrm{D}$ which is split into ${ }^{5} \mathrm{~T}_{2 \mathrm{~g}}$ and ${ }^{5} \mathrm{Eg}$ states so the transition can be assigned to ${ }^{5} \mathrm{~T}_{2 \mathrm{~g}} \rightarrow{ }^{5} \mathrm{E}_{\mathrm{g}}$ while for $\mathrm{d}^{6}$ low spin case, the ground state is ${ }^{1} \mathrm{~A}_{1 \mathrm{~g}}$ and there are two singlet excited states, ${ }^{1} \mathrm{~T}_{1 \mathrm{~g}}$ and ${ }^{1} \mathrm{~T}_{2 \mathrm{~g}}$ and the two observed spectral transitions are assigned as ${ }^{1} \mathrm{~A}_{1 \mathrm{~g}} \rightarrow{ }^{1} \mathrm{~T}_{1 \mathrm{~g}}$ and ${ }^{1} \mathrm{~A}_{1 \mathrm{~g}} \rightarrow{ }^{1} \mathrm{~T}_{2 \mathrm{~g}}$ (Lever, 1984). The electronic spectrum for synthesized Co (III) complex showed only one band at $436 \mathrm{~nm}$ which is assigned to ${ }^{5} \mathrm{~T}_{2 \mathrm{~g}} \rightarrow{ }^{5} \mathrm{E}_{\mathrm{g}}$ transition with octahedral geometry around central Co(III).

\section{CONCLUSION}

The cobalt(III) complex, which was synthesized by using $\mathrm{H}_{2} \mathrm{sbh}$ and $\mathrm{Co}\left(\mathrm{NO}_{3}\right)_{2} \cdot 6 \mathrm{H}_{2} \mathrm{O}$ was characterized on the basis of ligand estimation, metal estimation , dehydration study, IR and electronic spectra. The ligand $\mathrm{H}_{2}$ sbh was found to coordinate with cobalt (III) in enolic form. The composition corresponds to a 1:2 metal : ligand ratio. Dehydration study showed the presence of three lattice and one coordinated water molecule. The IR spectra showed coordination through enolic oxygen and azomethine nitrogen. Electronic spectra in visible range show octahedral geometry around central Co (III). Based on the various physico-chemical studies, the structure as shown in Fig 3 have been tentatively proposed for cobalt complex with $\mathrm{H}_{2} \mathrm{sbh}$.

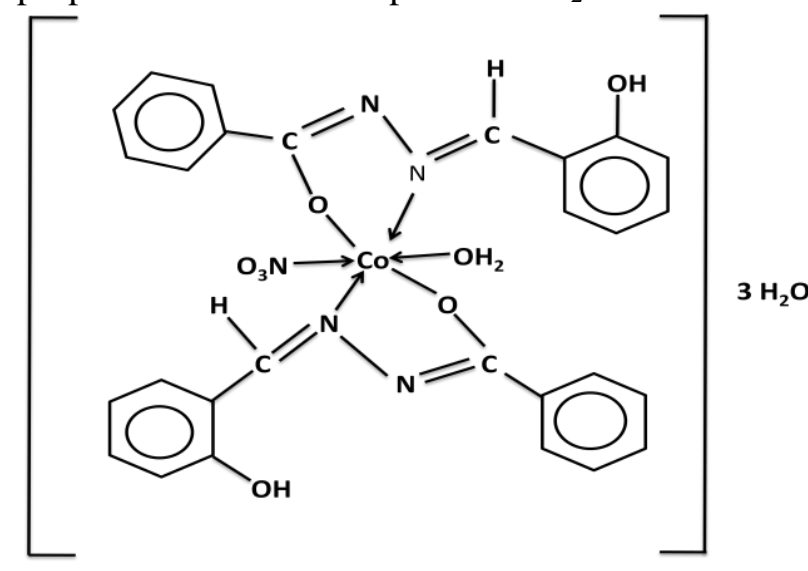

Fig. 3. Proposed Structure of $\left[\mathrm{Co}(\mathrm{Hsbh})_{2}\left(\mathrm{NO}_{3}\right)\left(\mathrm{H}_{2} \mathrm{O}\right)\right] .3 \mathrm{H}_{2} \mathrm{O}$. 


\section{ACKNOWLEDGEMENTS}

Author would like to thank Central Department of Chemistry, Tribhuvan University for providing the laboratory facility, Nepal Academy of Science and Technology, for recording electronic spectra and IR Spectra.

\section{REFERENCES}

Bandin, R.; Bastida, R.; Blas, A.; Castro, P.; Fenton, D. E. Macías, A.; Rodríguez, A. and Rodríguez, T. (1994). Complexes of lanthanide ions with a schiff-base macrocylic ligand derived from 2, 6-Diformylpyridene. Journal of Chemical Society Dalton Transaction, 8: 1185-1188.

Demirelli, H.; Tumer, M. and Golcu, A. (2006). Synthesis and characterization of polydentate schiff-base ligands and their complexes. Bulletin of Chemical Society of Japan, 79 (6): 867-875.

Lever, A. B. P. (1984). Inorganic electronic spectroscopy, $2^{\text {nd }}$ ed; Elsevier: New York.

Geary, W. J. (1971). The use of conductivity measurements in organic solvents for the characterization of coordination compounds, Coordination Chemistry Review, 7: 81.

Mohan, M.; Kumar, A.; Kumar, M. and Jha, N. K. (1987). Synthesis, characterization and antitumor activity of Manganese (II), Cobalt (II), Nickel (II), Copper (II), Zinc (II) and Platinum (II) complexes of 3- and 5substituted salicylaldehyde benzoyl hydrazone. Inorganica Chemica Acta, 136: 65.

Nakamoto, K. (1997). Infrared and Raman spectra of coordination compounds, $5^{\text {th }}$ edn, John Wiley and Sons, New York.

Narang, K. K.; Rao, T. R.; Shrestha, S. and Shrestha, S. (2000). Synthesis, characterization, thermal and electrical properties of Yttrium(III) and Lanthanide (III) complexes of salicylaldehyde benzoyl hydrazone. Synthesis Reactivity in Inorganic Metal-Organic Chemistry, 30 (5): 931-954.
Narang, K. K.; Singh, V. P.; Mishra, S. K. and Mishra, G. D. (1996). Synthesis, characterization, $\mathrm{x}$-ray diffraction studies and antifungal activity of $\mathrm{Co}$ (III) complexes with some aroylhydrazide. Synthesis Reactivity Inorganic Metal-Organic Chemistry, 26 (2): 191-209.

Sayeed, L.; El and Iskander, M. F. (1971). Coordination compounds of hydrazine derivatives with transition metals-III: The reaction of aroyl hydrazones with $\mathrm{Ni}(\mathrm{II})$ and $\mathrm{Cu}(\mathrm{II})$ salts. Journal of Inorganic Nuclear Chemistry; 33: 435.

Shrestha, S. and Maharjan, S. (2012). Synthesis and characterization of copper complex of salicylaldehyde benzoyl hydrazone. Journal of Nepal Chemical Society, 29:11-17.

Shrestha, S. (2013). Synthesis and spectroscopic characterization of schiff base with Ni (II) ion. Journal of Institute of Science and Technology, 18 (1): 84-88.

Silverstein, R. M.; Bassler, G. C. and Morrill, T. C. (1981). "Specrometric Identification of Organic Compounds", John Wiley and Sons, New York, Fourth Edition, 1981.

Vogel, A. I. (1978). A Text Book of Quantitative Inorganic Analysis. Fourth Edition, ELBS, London.

Yongxiang, M.; Zhengzhi, Z.; Yun, M. and Gang, Z. (1989). Cobalt complexes of formyl ferrocene m- nitro benzoyl hydrazone with lanthanide, Inorganica Chemica Acta, 165 (2): 185-189.

Zabicky, Z. (1970). The chemistry of amides. Interscience publishers. London, pp. 515. 